Counsellia: Jurnal Bimbingan dan Konseling 8 (2) 88-99 November 2018

Copyright (C2017 Universitas PGRI Madiun

ISSN: 2088-3072 (Print) / 2477-5886 (Online)

Available online at: http://e-journal.unipma.ac.id/index.php/JBK

DOI: $10.25273 /$ counsellia.v8i2.2693

\title{
Hubungan kontrol diri dengan perilaku bullying Siswa
}

\author{
Salmi Salmi ${ }^{1}$; Rezki Hariko ${ }^{2}$; Afdal Afdal ${ }^{3}$ \\ ${ }^{1}$ FIP, Universitas Negeri Padang, Padang \\ salmi2247@gmail.com \\ ${ }^{2}$ FIP, Universitas Negeri Padang, Padang \\ hariko@konselor.org \\ ${ }^{3}$ FIP, Universitas Negeri Padang, Padang \\ afdal@konselor.org
}

\begin{abstract}
Abstrak
Perasaan aman dan nyaman berada di sekolah sangat dibutuhkan oleh setiap siswa untuk menunjang pengembangan potensinya. Fenomena yang terjadi terdapat beberapa siswa yang mengalami kekerasan di sekolah berupa perilaku bullying. Kemunculan perilaku ini dapat disebabkan oleh berbagai faktor, salah satunya yaitu kontrol diri. Penelitian bertujuan untuk mendeskripsikan kontrol diri dan perilaku bullying siswa, serta menguji hubungan kontrol diri dan perilaku bullying siswa. Penelitian ini merupakan penelitian deskriptif dan korelasional dengan subjek penelitian 47 siswa. Penelitian menggunakan instrumen angket yang disusun dengan meggunakan model skala likert. Data diolah dengan teknik statistik deskriptif dan untuk uji korelasi kedua variabel digunakan rumus product moment correlation. Hasil penelitian mengungkapkan terdapat hubungan yang signifikan antara kontrol diri dengan perilaku bullying siswa.
\end{abstract}

Kata kunci: kontrol diri, perilaku bullying, siswa

\begin{abstract}
Feelings of comfort and secure in the school is needed by every student to support the development of potentialities. The phenomenon that occurs there are some students who experienced violence in schools in the form of bullying behavior. The appearance of this behavior can be caused by various factors, one of which is self-control. The study aims to describe self-control and bullying behavior of students, as well as to examine the relationship of self-control and student bullying behavior. This research is a descriptive and correlational research with subject of research of 47 students. The research used questionnaire instrument that was prepared using Likert scale model. Data is processed by descriptive statistical techniques and for the correlation test of both variables used product moment correlation formula. The results revealed there was a significant relationship between student's self-control and bullying behavior.
\end{abstract}

Keywords: self-control, bullying behavior, students

\section{PENDAHULUAN}

Sekolah merupakan lembaga pendidikan formal yang berfungsi sebagai wadah bagi pengembangan potensi dan aktualisasi diri siswa.
Sekolah adalah lingkungan artifisial yang sengaja dibentuk guna mendidik dan membina generasi muda ke arah tujuan tertentu, terutama membekali siswa dengan 
pengetahuan dan kecakapan hidup yang dibutuhkan dikemudian hari (Deswita, 2012). Sebagai individu remaja, siswa mengalami proses transisi perkembangan menuju kedewasaan. Salah satu faktor yang paling melindungi saat mereka tumbuh adalah memiliki beberapa persahabatan yang sehat dari SD hingga SMA dan dewasa (Tharsis, 2010). Kenyataan yang terjadi di dunia pendidikan saat ini masih terdapat tindak kekerasan seperti adanya kasus bullying. Menurut Coloroso (2007) bullying merupakan tindakan intimidatif yang dilakukan pihak yang kuat terhadap pihak yang lemah, kuat secara fisik dan mental serta dapat terindentifikasi melalui bentuk kekerasan secara fisik, kekerasan secara verbal dan atau kekerasan secara relasional.

Perilaku bullying dipengaruhi oleh beberapa faktor, salah satunya disebabkan kontrol diri yang rendah (Taufik, 2014). Hal ini didukung oleh pendapat Wiyani (2012) yang menyatakan kemampuan mengontrol diri dapat mengikis praktik terjadinya kasus bullying. Thalib (2010) menyatakan kontrol diri sebagai kemampuan individu dalam mengendalikan dorongan baik dari dalam diri maupun luar diri individu. Selanjutnya Baumeister (2007) menyatakan kontrol diri mengacu pada kapasitas untuk mengubah respon seseorang, terutama untuk membawa mereka sesuai dengan standar seperti cita-cita, nilai, moral dan harapan so- sial serta untuk mendukung pencapaian tujuan jangka panjang. Dapat dipahami kontrol diri berkaitan dengan kemampuan individu dalam menampilkan konsekuensi positif dari yang dilakukannya.

Perilaku bullying dapat menyebabkan dampak serius, sehingga tidak dapat dianggap sebagai perilaku biasa. Dampak perilaku bullying menyebabkan luka batin bagi korbannya dan bahkan ada korban yang bunuh diri (SEJIWA, 2008). Hasil penelitian Bank (Saripah, 2010) mengungkap kejadian di dunia terhadap bullying terjadi setiap tujuh menit. Selain itu, penelitian Nansel (Santrock, 2007) mengungkap hampir satu dari tiga siswa yang menjadi korban dan pelaku bullying. Kemudian perolehan data hasil penelitian Zulfiyaturrizqiyah mengungkap setiap jenjang kelas terdapat peluang terjadinya kasus bullying dan persentase terbesar terjadi di kelas tujuh dan kelas delapan. Berita dari Purbaya (2018) mengungkapkan adanya siswa yang ditemukan meninggal di kolam renang, setelah menerima perlakuan bullying dari kakak tingkatnya saat ada agenda organisasi sekolah.

Data pada Komisi Perlindungan Anak Indonesia (KPAI) menunjukkan dalam rentang tahun 2011-2017 terdapat aduan 26 ribu kasus bully (Setiawan, 2016) Lebih khusus untuk bullying, tercatat 122 anak yang menjadi korban dan 131 
anak yang menjadi pelaku (Muthmainah, 2017). Selanjutnya berdasarkan data KPAI tercatat anak sebagai pelaku bullying (kekerasan) di sekolah mengalami kenaikan dari 67 kasus (2014) menjadi 79 kasus (2015) (Wijayaka, 2015). Kemudian hasil monitoring dan evaluasi KPAI pada April 2012 terhadap sembilan Provinsi yaitu Sumatera Barat, Lampung, Jambi, Banten, Jawa Tengah, DIY, Jawa Barat, Jawa Timur, dan Kalimantan Timur ditemukan angka kekerasan yang cukup tinggi di sekolah, menyatakan 66,5 persen atau 628 anak pernah mengalami kekerasan yang dilakukan guru, 74,8 persen 767 anak pernah mengalami kekerasan yang dilakukan teman sekelas $(74,8$ $\%)$, dan sebanyak 578 (56,3 \%) anak pernah mengalami kekerasan yang dilakukan teman lain kelas (Harian Rakyat Merdeka, 2017).

Penelitian ini dilakukan untuk mendeskripsikan kontrol diri dan perilaku bullying siswa, serta menguji hubungan kontrol diri dengan perilaku bullying siswa.

\section{METODE PENELITIAN}

Penelitian ini merupakan penelitian deskriptif kuantitatif jenis korelasional. Penelitian ini dilakukan di SMP N 26 Padang dengan jumlah subjek penelitian 47 orang siswa. Instrumen yang digunakan dalam penelitian ini adalah skala model Likert. Data dianalisis melalui teknik statistik dengan menentukan nilai skor dan persentase dan analisis korelasional menggunakan rumus Product Moment Correlation.

\section{HASIL DAN PEMBAHASAN}

Hasil penelitian memberikan gambaran kontrol diri dan perilaku bullying siswa serta hubungan kedua variabel tersebut. Kontrol diri mencakup aspek behavioral control, cognitive control dan decision control. Perilaku bullying berupa kekerasan secara fisik, kekerasan secara verbal dan kekerasan secara relasional. Secara umum untuk seluruh sub variabel, terdapat hubungan yang signifikan antara kontrol diri dan perilaku bullying. Secara khusus gambaran kedua variabel dan hubungannya dapat terlihat pada diagram dan tabel berikut.

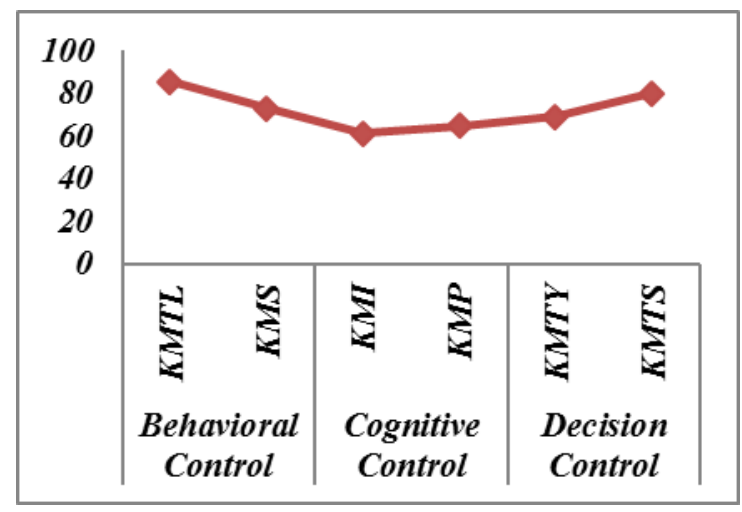

Diagram 1. Gambaran Kontrol Diri Siswa

Catatan:

KMTL: Kemampuan mengatur tingkah laku

KMS : Kemampuan Mengatur Stimulus

KMI : Kemampuan memperoleh informasi 
KMP : Kemampuan melakukan penilaian

KMTY: Kemampuan memilih tingkahlaku sesuai dengan yang diyakini

KMTS : Kemampuan memilih tingkahlaku sesuai yang disetujui

Berdasarkan Diagram 1 diatas terlihat gambaran kontrol diri siswa pada aspek behavioral control, cognitive control dan decision control. Behavioral control berkaitan dengan kesiapan tersedianya suatu respons yang dapat secara langsung mempengaruhi atau memodifikasi suatu keadaan yang tidak menyenangkan (Ghufron, 2011). Perilaku yang ditampilkan seseorang menyaratkan adanya suatu informasi yang direspon kemudian ditampilkan dalam bentuk perilaku. Hasil penelitian menunjukkan kemampuan mengatur stimulus dalam hal menolak ajakan teman berbicara saat proses belajar berlangsung, mematuhi tata tertib sekolah, memperhatikan materi yang disampaikan guru saat teman banyak sibuk sendiri, mengintropeksi diri ketika di nyatakan melakukan kesalahan dan mengusahakan untuk sabar ketika tersinggung perkataan teman masih rendah. Hasil penelitian menunjukkan kemampuan mengatur tingkahlaku lebih baik dibandingkan dengan kemampuan mengatur stimulus.

Kemampuan mengatur stimulus berkaitan dengan respon yang akan dimunculkan, yang dalam aliran behavioristik dikenal dengan pembentukan tingkah laku sebagai hubungan antara stimulus dengan respon yang bisa diamati dan tidak menghubungkan dengan kesadaran maupun konstruksi mental (Rusuli, 2014). Penelitian Warisman (2016) telah membuktikan bahwa kemampuan dalam mengatur stimulus ini mempengaruhi terhadap perilaku yang ditampilkan seseorang, melalui pengaturan stimulus yang dilakukan mampu meningkatkan perilaku kearah lebih baik. Cara yang dapat dilakukan agar kemampuan ini lebih baik, yaitu dengan mencegah atau menjauhi stimulus, menghentikan stimulus sebelum waktunya berakhir, dan membatasi intensitasnya (Thalib, 2010).

Kemampuan mengatur tingkahlaku berkaitan dengan kemampuan individu untuk menentukan siapa yang mengendalikan situasi atau keadaan (Ghufron, 2011). Hal ini menunjukkan siswa yang memiliki kemampuan yang baik dalam hal ini akan mampu mengatur perilaku dengan menggunakan kemampuannya sendiri (Thalib, 2010).

Control cognitive berkaitan dengan kemampuan siswa dalam mengolah informasi yang tidak diinginkan dengan cara menginterpretasi, menilai atau menghubungkan suatu kejadian dalam suatu kerangka kognitif sebagai adaptasi psikologis atau mengurangi tekanan (Ghufron, 2011). Siswa dengan kontrol kog- 
nitif yang baik mampu mendapatkan informasi, menganalisa informasi tersebut sehingga keputusannya objektif dan positif ketika menghadapi suatu keadaan. Upaya peningkatan kontrol kognitif dapat dilakukan dengan menerapkan cognitive behavior therapy. Sullivan (Sasmita dkk., 2010) menjelaskan cognitive behavior therapy sebagai pengobatan dengan pendekatan terhadap konsep dasar jalan pikiran dan bagaimana meresponnya. Terapi yang dilakukan berorientasi pada kegiatan dalam merubah kognitif yang negatif dan perilaku maladaptif menjadi kognitif yang positif dan perilaku yang adaptif. Terkait dengan kontrol kognitif di dalamnya terdapat gaya kognitif yang menggambarkan perbedaan individu yang konsisten dalam mengalami, mengatur dan memproses informasi, Martisen dan Kaufman (Jailani \& Lahinda, 2015). Keterampilan dalam kontrol kognitif dapat meningkatkan kemampuan untuk membuat pertimbangan sosial dan mengontrol perilaku, Elkind \& Weiner (Widiana, 2004). Berawal dari kemampuan dalam menerima informasi, hingga nantinya tampil dalam bentuk perilaku yang telah diputuskan, terdapat kontrol perilaku yang juga perlu ditingkatkan siswa.

Hasil penelitian menunjukkan kontrol kognitif siswa lebih baik dalam hal kemampuan melakukan penilaian daripada kemampuan memperoleh informasi. Artinya informasi yang dimiliki siswa mengenai suatu keadaan belum mampu membuatnya mengantisipasi keadaan melalui berbagai pertimbangan objektif. Selanjutnya berpengaruh terhadap penilaian yang dilakukan sebagai usaha menilai keadaan secara positif.

Decision control berkaitan dengan kemampuan seseorang untuk memilih hasil atau suatu tindakan berdasarkan pada sesuatu yang diyakini dan disetujuinya. Pada dasarnya individu memiliki kemampuan dalam mengambil keputusan, tetapi tidak semua orang mampu mengambil keputusan sendiri secara tepat (Fatimah, 2010). Syarat yang dibutuhkan sehingga mampu menentukan keputusan yang rasional meliputi keterangan yang diperoleh berdasarkan fakta, bebas dari prasangka, bersih, jauh dari pertimbangan subjektif, berusaha dapat mencapai tujuan, dapat mengetahui dengan jelas tujuan mana yang dapat dicapai beserta berbagai kelemahannya, berdasarkan prinsipprinsip analisis dalam menilai berbaia alternatif sesuai dengan tuntutan untuk mencapai tujuan, menggunakan ukuran subjektif, didasarkan pada teknik kuantitatif serta bersikap optimis dan berkemauan yang kuat memilih alternatif yang paling baik (Sari, 2018).

Berikut ini gambaran ini perilaku bullying siswa meliputi aspek kekerasan secara fisik, kekerasan 
secara verbal dan kekerasan secara relasional.

meminta paksa benda milik orang lain (Asp.1.3) dengan bentuk meminta uang teman meskipun teman tersebut keberatan memberikannya, memakan makanan teman tanpa minta persetujuan darinya, dan menggunakan buku teman meskipun tidak diizinkan.

Kekerasan fisik akan berimplikasi

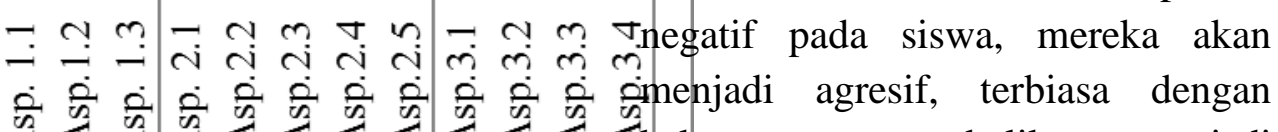

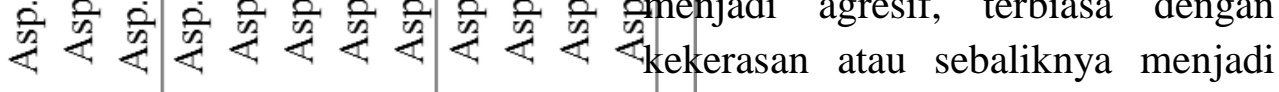
fisik verbal relasional anak yang tidak percaya diri, inferior

Diagram 2. Gambaran Perilaku Bullying Siswa

Berdasarkan Diagram 2 diatas terlihat gambaran perilaku bullying siswa pada aspek kekerasan secara fisik, verbal dan relasional. Pada aspek kekerasan fisik (Asp. 1.1) terlihat bahwa perilaku menyakiti anggota tubuh korban yang dilakukan siswa berada pada tingkat lebih tinggi, yang menunjukkan adanya siswa yang mendorong kepala teman yang tidak jelas isi pembicaraannya, mendorong teman yang mengganggu kesenangan diri pribadi, melempar dengan barang terdekat teman yang menentang permintaan yang diinginkan, melempar dengan kertas teman yang sedang serius belajar, mendorong badan teman yang menghalangi saat berjalan. Selanjutnya merusak benda milik korban (Asp.1.2), yang ditunjukkan dengan mencoret buku teman saat bosan dalam belajar, mematahkan pena teman jika tidak mau meminjamkannya. Kemudian dan selalu ketakutan untuk melakukan sesuatu dan ketakutan mencoba sesuatu yang baru sebagai ekspresi kreativitas dan inovasinya (Rosyada, 2017). Akibat dari kekerasan ini, adanya kerusakan organ-organ tubuh siswa (Harefa, 2016). Terlihat jelas kekerasan yang dilakukan menimbulkan banyak dampak negatif.

$\begin{array}{lrr}\quad \text { Kekerasan } & \text { verbal } & \begin{array}{r}\text { siswa } \\ \text { perilaku }\end{array} \\ \text { menunjukkan } & & \begin{array}{r}\text { (Asp.2.4) } \\ \text { mempermalukan }\end{array} \\ \text { mengambil posisi } & \text { tertinggi }\end{array}$

dilanjutkan dengan julukan nama yang buruk (Asp.2.1), berkata kasar (Asp.2.3), menghina (Asp.2.2) dan mengancam

(Asp.2.5). Mempermalukan yang dilakukan siswa berkaitan dengan menertawakan teman yang terbatabata menyampaikan pendapat di kelas, menyoraki teman yang salah menjawab pertanyaan guru, menyampaikan kesalahan teman di tempat umum. Julukan nama yang buruk berkaitan dengan memanggil 
teman dengan nama samaran yang tidak disukainya, memanggil teman sesuai postur tubuhnya seperti gendut, kurus. Berkata kasar ditampilkan dalam memaki teman yang berjalan duluan tanpa permisi, memaki teman yang membuat marah, memarahi teman yang mengingatkan guru mengumpulkan PR, dan membentak teman yang ikut menertawakan kesalahan yang dibuat. Mengina tampil dalam bentuk menertawakan teman yang berpenampilan berbeda dari siswa lain, menertawakan kekurangan teman di depan banyak orang, mengejek teman yang berjalan sendirian berangkat ke sekolah. Mengancam meliputi menggertak akan memukul teman yang tidak mau memberikan contekan, menggertak akan mengajak orang lain menjauhi teman yang menentang perintah, menggertak akan berkata kasar kepada teman yang membuat marah.

Kekerasan yang ditunjukkan siswa ini menunjukkan adanya penggunaan stereotipe dan penamaan yang bermuatan seks, rasis, kultur, sosio-ekonomi, ketidaksempurnaan fisik dan homofobik (Yaumi, 2016). Akibat dari kekerasan ini merusak hak dan perlindungan korban, menyakitkan dan melecehkan (Wicaksana, 2008). Selain itu, hilangnya minat belajar, malas/takut untuk datang ke sekolah, menjadi seorang pendiam, membalas balik dengan kata-kata kesat, timbul rasa benci terhada seseorang itu orang itu dianggap biadap dan musuh, membuli orang itu dan orang lain, tidak memperdulikan orang itu, lebih semangat belajar, mengelak diri daripada perlakukan dengan situasi demikian, menegur dan menasihati secara ramah, melaporkan kepada guru/guru disiplin, dan bertindak dengan lebih sederhana, rasional dan bijakasana juga akibat dari kekerasan secara verbal (Hamzah, 2012). Dari beberapa akibat yang ditimbulkan, dampak negatif mendomininasi.

Kekerasan relasional siswa, terlihat posisi teringgi pada perilaku bersikap sinis (Asp.3.4), sengaja mengucilkan/ mengabaikan (Asp.3.1), menggosipkan (Asp.3.2) dan memanipulasi persahabatan hingga retak (Asp.3.3). Bersikap sinis terlihat dari pandangan teman yang pernah tinggal kelas tidak mungkin jadi siswa berprestasi, memalingkan muka jika bertemu dengan teman yang tidak sukai, dan menghindar saat teman yang tidak sukai mendekat. Sengaja mengucilkan/mengabaikan terlihat dari tidak merespon ajakan anggota kelompok lain untuk berdiskusi, mengucilkan teman yang tidak memahami materi pelajaran walaupun telah dijelaskan oleh guru, sibuk dengan kegiatan lain saat teman mengajak berbicara, mengucilkan teman yang tidak bersedia membagi jawaban saat ujian, hanya akan berteman dengan orang yang mendengarkan pendapat diri pribadi, dan menolak teman yang ingin bergabung dengan kelompok 
yang telah ada. Menggosipkan tampak pada perilaku menyebarkan informasi negatif tentang teman tanpa mencari tahu kebenarannya, menyampaikan pada siswa lain tentang kecurigaan terhadap teman yang curang saat ujian dan berusaha meyakinkankan teman bahwa siswa yang mendapatkan nilai rendah karena bodoh. Kemudian memanipulasi persahabatan hingga retak dengan menghasut teman agar menjauhi anggota kelompok yang membocorkan rahasia, menyampaikan kejelekan teman yang diketahui agar kelompoknya menjauhi, dan menambah informasi negatif tentang anggota yang berbuat salah supaya ditolak dalam kelompok.

Kekerasan relasional terjadi ketika adanya pertemanan yang tidak sehat pada siswa. Sadar atas bentuk kepribadian, minat, keyakinan, dan kesenangan diri sendiri, tahu apa hobi, mata pelajaran, dan pengejaran yang dinikmati dan bagaimana menghabiskan waktu luang, mengenali sifat karakter dan nilai yang paling dihargai dan akan dijaga dengan cara apapun serta menemukan tujuan yang disukai dan melalui hal itu bisa terlibat dan bertemu oranglain yang memiliki pemikiran yang sama (Trittin \& Lawrence, 2014).

Pada tabel 1 berikut dikemukakan tentang hubungan antara kontrol diri dan perilaku bullying siswa.
Tabel 1.

Hubungan Kontrol Diri dengan

Perilaku bullying Siswa

\begin{tabular}{|ll|r|r|}
\hline & & $\begin{array}{c}\text { Kontro } \\
\text { 1 Diri }\end{array}$ & $\begin{array}{r}\text { Perilaku } \\
\text { Bullying }\end{array}$ \\
\hline Kontrol & $\begin{array}{l}\text { Pearson } \\
\text { Correlation }\end{array}$ & 1 & -.427 \\
Diri & $\begin{array}{l}\text { Sig. (2- } \\
\text { tailed) }\end{array}$ & & \\
& N & & .003 \\
& Pearson & & \\
Correlation & $-.427^{* *}$ & 1 \\
Perilaku & Sig. (2- \\
Bullying & & \\
& tailed) & .003 & \\
& $\mathrm{~N}$ & 47 & 47 \\
\hline
\end{tabular}

Berdasarkan tabel 1 tersebut dapat dilihat bahwa koefisien korelasi antara kontrol diri dengan perilaku bullying siswa sebesar 0.427 ( $\mathrm{r}$ hitung $=-0.427)$ dan sig. $(2$ tailed) senilai 0.003. Hipotesis penelitian diterima apabil $\mathrm{r}$ hitung $>$ rtabel dan sig. $(2$ tailed $)<0.05$. Berdasarkan pengujian hipotesis penelitian yang dilakukan $0.427>0.282$ dan $0.003<0.05$. Dengan demikian, dapat disimpulkan bahwa terdapat hubungan yang signifikan dan negatif antara kontrol diri dengan perilaku bullying siswa.

Perilaku bullying dipengaruhi oleh kontrol diri, jika siswa mampu mengontrol dirinya maka perilaku bullying siswa akan cenderung rendah. Kemudian, hal ini mendukung peacefull program yang dikemukakan oleh Wiyani (2012) yang menjadikan kemampuan mengontrol diri sebagai upaya dalam mengurangi bahkan menghilangkan 
praktek bullying. Individu dengan dengan kontrol diri yang tinggi sangat memperhatikan cara-cara yang tepat untuk berperilaku dalam situasi yang bervariasi, lebih fleksibel, berusaha memperlancar interaksi sosial, bersikap hangat dan terbuka. Dengan demikian, perilaku bullying yang terjadi dalam kekerasan secara fisik, verbal maupun relasional dapat dicegah dengan meningkatkan kontrol diri.

Berdasarkan hasil dan pembahasan penelitian, perlu dilakukan upaya-upaya peningkatan kontrol diri siswa yang pada muaranya secara otomatis diharapkan akan menurunkan terjadinya perilaku bullying. Upaya ini mesti dilakukan oleh segenap elemen yang ada di sekolah. Sebagai salah satu elemen terpenting sekolah, konselor sekolah dapat melakukan upaya-upaya tersebut melalui penyelenggaraan berbagai pelayanan bimbingan dan konseling, baik secara perorangan, klasikal maupun kelompok. Bimbingan dan konseling dapat dimaknai sebagai kegiatan profesional yang melibatkan hubungan antara seorang konselor dengan individu atau sekelompok individu (Hariko, 2017). Kegiatan yang melibatkan hubungan antara seorang konselor dengan seorang individu diselenggarakan dalam layanan konseling perorangan, yang merupakan inti dari penyelenggaraan pelayanan bimbingan dan konseling di sekolah secara keseluruhan
(Hariko, 2018). Sementara itu, penyelenggaraan pelayanan secara kelompok dapat dilaksanakan melalui penyelenggaraan bimbingan kelompok dan konseling kelompok. Terkait dengan hal ini, hasil penelitian Firman, Karneli \& Hariko (2018) mengungkapkan bahwa penggunaan pedoman konseling kelompok efektif untuk mencegah tindak kekerasan pada siswa.

\section{SIMPULAN}

Hasil penelitian menunjukkan kontrol diri yang baik mampu mencegah terjadinya perilaku bullying. Kemampuan kontrol diri berkaitan dengan keterampilan emosional seseorang yang mempengaruhi seseorang dalam memimpin dirinya yang ditunjukkan dengan mampu melibatkan diri dengan lingkungan secara lebih responsif, menyesuaikan diri dan kemampuan bebas memilih secara obyektif. Perilaku bullying siswa menunjukkan adanya kekerasan yang dilakukan baik secara fisik, verbal ataupun relasional, yang dapat menyebabkan korbannya mengalami kerugian secara fisik atau psikologis. Penyebabnya bervariasi mulai dari faktor ekstrinsik maupun faktor instrinsik yang dapat dicegah melalui peningkatan kemampuan keterampilan soft skill siswa. Terkait dengan temuan ini, konselor perlu meningkatkan kontrol diri dan mencegah perilaku bullying melalui pemberian pelayanan Bimbingan dan 
Konseling serta diperlukan penelitian lebih lanjut khususnya terkait faktor teman sebaya dalam hubungan dengan kontrol diri dan perilaku bullying.

\section{DAFTAR PUSTAKA}

Baumeister, R. F. dkk. (2007). The Strenght Model of Self Control. Association for Psychological Science, 16, 351-355.

Coloroso, B. (2007). Stop Bullying! Memutus Rantai Kekerasan Anak Prasekolah hingga SMU. Jakarta: Serambi Ilmu Semesta.

Deswita. (2012). Psikologi Perkembangan Peserta Didik. Bandung: Remaja Rosdakarya Offset.

Fatimah, N. R. (2010). Peningkatan Kemampuan Pengambilan Keputusan Melalui Layanan Bimbingan Kelompok Pada Siswa Kelas X.5 Di SMA Negeri 2 Ungaran. Skripsi.Universitas Negeri Semarang.

Firman, F., Karneli, Y., \& Hariko, R. (2018). Improving Students' Moral Logical Thinking and Preventing Violent Acts Through Group Counseling in Senior High Schools. Advanced Science Letters, 24(1), 24-26.

Ghufron, M. N. dkk. (2011). Teoriteori Psikologi. Yogyakarta: Ar Ruzz Media.

Hamzah, Z. A. B. Z. (2012). Perilaku Berbahasa Kasar dalam Kalangan Remaja Sekolah. In Singapore International Journal of Language and Literature (pp. 112-117). Sarawak: Singapore
International Press.

Harefa, B. (2016). Kapita Selekta Perlindungan Hukum Bagi Anak. Yogyakarta: Deepublish.

Hariko, R. (2017). Landasan Filosofis Keterampilan Komunikasi Konseling. Jurnal Kajian Bimbingan dan Konseling, 2(2), 41-49.

Hariko, R. (2018). Are High School Students Motivated to Attend Counseling?. COUNS-EDU:

The International Journal of Counseling and Education, 3(1), 14-21.

Jailani \& Lahinda, Y. (2015). Analisis Proses Pemecahan Masalah Matematika Siswa Sekolah Menengah Pertama. Jurnal Riset Pendidikan Matematika, Vol. 2 No., 148161.

Merdeka, H. R. (2017). 767 Siswa Di 9 Provinsi Alami Kekerasan Di Sekolah. Retrieved from http://www.rmol.co/read/2012/0 8/02/73246/767-Siswa-Di-9Provinsi-Alami-Kekerasan-DiSekolah-

Muthmainah, D. A. (2017). Semakin Banyak yang Melaporkan Kasus "Bullying". Retrieved from https://www.cnnindonesia.com/ gaya-hidup/20170722163858277-229641/semakin-banyakyang-melaporkan-kasusbullying

Purbaya, A. A. (2018). SMAN 1 Semarang Blak-Blakan Kasus Bullying Berujung 2 Siswa Dipecat. Retrieved from https://news.detik.com/beritajawa-tengah/d-3894976/sman-1semarang-blak-blakan-kasusbullying-berujung-2-siswadipecat.html 
Rosyada, D. (2017). Madrasah dan Profesionalisme Guru dalam Arus Dinamika Pendidikan Islam di Era Otonomi Daerah. Depok: Kencana.

Rusuli, I. (2014). Refleksi Teori Behavioristik Dalam Perspektif Islam. Jurnal Pencerahan, 8 (1)

Santrock, J. W. (2007). Remaja. Jakarta: Erlangga.

Sari, F. (2018). Metode dalam Pengambilan Keputusan. Yogyakarta: Deepublish.

Saripah, I. (2010, November). Model Konseling Kognitif Perilaku Untuk Menanggulangi Bullying Siswa. In Proceedings of The 4th International Conference On Teacher Education: Join Conference Upi \&Upsi Bandung, Indonesia (pp. 720726).

Sasmita, H., Keliat, B. A., \& Budiharto, B. (2010). Peningkatan Kemampuan Kognitif dan Perilaku Pada Klien dengan Harga Diri Rendah Melalui Cognitive Behaviorur Therapy. Jurnal Keperawatan Indonesia, 13(1), 26-31.

Setiawan, D. (2016). Mengejutkan! Bullying di Sekolah Meningkat, Jadi Perhatian Serius Jokowi dan KPAI. Retrieved from http://www.kpai.go.id/berita/me ngejutkan-bullying-di-sekolahmeningkat-jadi-perhatianserius-jokowi-dan-kpai/

Taufik. (2014). Mencegah dan Mengatasi Tingkah Laku Bullying Melalui Layanan Bimbingan kelompok. In Proceeding Guidance and Counseling International Seminar and Workshop.
Thalib, S. B. (2010). Psikologi Pendidikan Berbasis Analisis Empiris Aplikatif. Jakarta: Kencana.

Tharsis, T. P. (2010). Thomas Paul Tharsis. America: Facts On File.

Tim Yayasan Semai Jiwa Amini (SEJIWA). (2008). Mengatasi Kekerasan di Sekolah dan Lingkungan Sekitar Anak. Jakarta: Grasindo.

Trittin, D., \& Lawrence, A. (2014). Parents, Are you ready to Launch. Jakarta: Kesain Blanc.

Warisman, E. (2016). Penerapan Metode Stimulus Response Learning untuk Meningkatkan Hasil Belajar Siswa Pada Pembelajaran IPS tentang Lingkungan Alam Sekitar, 4 No. 2. Retrieved from antologi.upi.edu/file/TURUNA N_SKRIPSI

Wicaksana, I. (2008). Mereka Bilang Aku Sakit Jiwa. (Kanisius, Ed.). Yogyakarta.

Widiana, H. S. dkk. (2004). Kontrol Diri dan Kecendrungan Kecanduan Internet. Indonesian Psychologycal Journal, Vol. 1 No., 6-16.

Wijayaka, B. (2015). Pelaku Kekerasan di Sekolah Meningkat. Retrieved from http://www.beritasatu.com/kesra /337018-pelaku-kekerasan-disekolah-meningkat.html

Wiyani, N. A. (2012). Save Our Children from School Bullying. Yogyakarta: Ar Ruzz Media.

Yaumi, M. (2016). Pendidikan Karakter: Landasan, Pilar dan Implementasi. Jakarta: Prenadamedia Group.

Zulfiyaturrizqiyah. (2012). Perilaku Bullying di Kalangan Remaja 
Awal (Studi Fenomenologi Sekolah Menengah Pertama). Skripsi. Universitas Negeri Malang. 